\title{
Inheritance Distribution of Adopted Children in The Perspective of Customary Law and Islamic Law Compilation: Case Study of the Application of Inheritance Law in Kudus
}

\author{
Abdurrohman Kasdi' ${ }^{1}$, Khoiril Anwar ${ }^{2}$ \\ 1,2Intitut Agama Islam Negeri Kudus - Indonesia \\ e-mail: abdurrohmankasdi@iainkudus.ac.id
}

\begin{abstract}
This article aims to examine the position of adopted children, determine the position of adopted children's inheritance rights, as well as the application of the distribution of inheritance for adopted children in Customary Law and Compilation of Islamic Law in Kudus Regency. The method used is qualitative with a comparative approach. The results showed that the teachings of Islam did not deny the existence of adopted children as far as giving welfare and education to children. The position of adopted children in customary law is influenced by the family or family system. Their position from one region to another varies. In the case of the application of the distribution of inheritance for adopted children in adat law in Kudus District, several provisions of customary law state that the portion of adopted children is equated with the portion of biological children (if there is inheritance rights), or through the will of their adopted parents. While the application of Islamic Law Compilation in the distribution of inheritance in Kudus Regency also regulates wasiat wajibah, a will determined by law even though the person concerned does not inherit it.
\end{abstract}

Keywords: inheritance; adopted children; customary law; Islamic Law Compilation

\section{[1}

Artikel ini bertujuan mengkaji kedudukan anak angkat, mengetahui posisi hak waris anak angkat, sekaligus penerapan pembagian harta waris bagi anak angkat dalam Hukum Adat dan Kompilasi Hukum Islam di Kabupaten Kudus. Metode yang digunakan adalah kualitatif dengan pendekatan komparatif. Hasil penelitian menunjukkan bahwa ajaran Islam tidak memungkiri adanya anak angkat sejauh untuk memberi kesejahteraan dan pendidikan kepada anak. Kedudukan anak angkat dalam hukum adat dipengaruhi oleh sistem keturunan atau kekeluargaan. Kedudukan mereka dari satu daerah dengan daerah yang lain berbeda-beda. Dalam hal penerapan pembagian harta waris bagi anak angkat dalam hukum adat di Kabupaten Kudus beberapa ketentuan hukum adat menyatakan porsi anak angkat disamakan dengan porsi anak kandung (apabila ada hak waris), atau melalui cara wasiat dari orang tua angkatnya. Sedangkan penerapan Kompilasi Hukum Islam dalam pembagian waris di Kabupaten Kudus juga mengatur wasiat wajibah, wasiat yang ditentukan oleh perundang-undangan walaupun yang bersangkutan tidak mewasiatkannya.

Kata Kunci: warisan; adopsi anak; hukum adat; Kompilasi Hukum Islam 


\section{Introduction}

For parents, children are the greatest gift of Allah. Moreover, they are the more precious wealth rather than others. They are as a trust of Allah who must be constantly maintained and protected because they have dignity and rights as a human being which must be upheld which is children's rights. When parents do not have children and have raised and grown children with all love and care for a long time, so that they grow physically and mentally, then they are considered as a part of their own family. They are protected from all forms of danger that may threaten their life, they are given the embrace of love every time so that the children becomes a soulmate who cannot be separated from them.

In Islam, the allowed adoption of children is adoption that is not attaching the nasab to those adopted children, so that his position does not affect inheritance. ${ }^{1}$ This can be understood from the verses of the Qur'an, al-Ahzāb verse 37, where asbāb al-nuzūl of this verse was when the Prophet asked by Allah to marry Zaynab who incidentally was the ex-wife of his adopted son, Zaid bin Harisah. ${ }^{2}$ Islam does not forbid a person or a family from adopting someone else's child as his child. The child is called an adopted child and person who adopts him is called an adopted parent ${ }^{3}$

In Civil Law as well as Islamic Law4 which are commonly used to explain the matter of inheritance, it is stated that adopted children are not included in a person's heir. However, in the perspective of custom institutions, the determination of inheritance rights for adopted children depends on the regulated customary law. For families who keep the principle of parental, in Java, for example, adoption does not automatically cut the family relationship between children with biological parents. Therefore, in addition to obtaining inheritance rights from his adoptive parents, children also still have the right to inherit from his biological parents. On the other hand, in Bali, adoption of a child

\footnotetext{
1Franz and Keebet Von Benda-Beckmann, 'Islamic Law in a Plural Context: The Struggle over Inheritance Law in Colonial West Sumatra', Journal of the Economic and Social History 55 (2012): 77193, https://doi.org/10.1163/15685209-12341269.

2Mifa Al-Fahmi, 'Warisan Anak Angkat Menurut Hukum Adat Dan Kompilasi Hukum Islam', USU Law Journal 5, no. 1 (2017): 1.

3Yasin, Titik Temu Hukum Waris Di Indonesia (Yogyakarta: Idea Press, 2011), 170.

${ }^{4} \mathrm{Abu}$ Hapsin, 'How to Make Islamic Law as The State Legal Policy of Indonesia: Constitutional and Sociological Arguments', Al-Ahkam 27, no. 2 (2017): 140-41.
} 
is considered as a Law obligation to release the child from his or her original family to enter his adopted family. The child becomes the biological child of the person who raised him and continues the position of his adoptive parents.

Research in this paper use qualitative method. By choosing this qualitative method, the writer wants to obtain complete and accurate data. In this study, the authors used a comparative approach, ${ }^{5}$ to compare the compilation of Islamic law and customary law in the distribution of inheritance to adopted children. In order to the data in this study is accounted for as scientific research, it is necessary to test the validity of the data. In determining the data validity (trustworthiness), it is required investgation techniques. Its prctice is based on a number of specific criteria. According to Sugiyono there are four criteria which are used, among of them: credibility, transferability, dependability and confirmability. ${ }^{6}$

Data collection techniques are interview, observation and library material. Furthermore, these data are processed using pattern descriptive analysis which describes all the data and the obtained information and then analyzed them, elaborate clearly and completely to the problems in accordance with the distribution of inherited weath of adopted children based on Customary Law of Inheritance and Islamic law Compilation by case study of legal Inheritance Application in Kudus. The used data analysis technique is the analysis of the interactive model of Miles and Huberman. The main activities of this model data analysis include: data collection, data reduction, data display, conclusion and verification. ${ }^{7}$

\section{The Existence of Inheritance}

The word inheritance comes from the Arabic, mirāth. The plural form is mawārith which means the inheritance of the dead person, which will be distributed to all heirs. The terms of inheritance is a study of how the distribution of inheritance in accordance with Islamic sharia. The mawārith study is also called Farä'ị Study. ${ }^{8}$

${ }^{5}$ Moh. Nazir, Metode Penelitian (Bogor: Ghalia Indonesia, 2017), 43.

6Sugiono, Metode Penelitian Pendidikan: Pendekatan Kuantitatif, Kualitatif dan R \& D Educational Research Methods: Quantitative, Qualitative and R\&D Approaches (Bandung: Alfabeta, 2008), 201.

${ }^{7}$ Matthew B. Miles and A. Michael Huberman, Analisis Data Kualitatif(Jakarta: UI-Press, 2000), 21.

${ }^{8}$ Tim Penyusun Depag, Fiqih, Departemen Agama (Jakarta, 2002), 5. 
In Islamic Inheritance Law, there are three reasons for people to get part of inheritance, among of them: kinship, marriage, and relative. There is another reason why people get inheritance, because of wala'. If a man liberates a slave, there will be a kinship between them called wala' al-'itq. By the existence of such a relationship, that man will inherit his slave who have liberated him, in case. the slave does not have heirs at all, ${ }^{9}$ either because of marital relationship or kinship. However, nowadays, the reason of inheritance because of wala' has lost meaning significantly. Because at this time there is not slavery. ${ }^{10}$

There are three elements which need to be considered in heirs and inheritance: ${ }^{11}$ inherited wealth (mawrüth); testator or people who are leaving inheritance (muwarrith); and heirs (wārith). Meanwhile, there are three inheritance requirements, among of them: ${ }^{12}$ first, heir's death. It means the death because of real death, h\}ukmi (according to the judge's decision) and taqdiri (supposedly). Without certainty about the heir's death, the inherited wealth should not be distributed to the heirs.

Second, the heir's life. It must be clear when the heir dies. This is because a heir becomes a substitute to control the inheritance left by the testator. The transfer of wealth is obtained through a process of inheritance. So after the testator dies, the heir must be really alive. Third, knowing status of inheritance. So that heirs can inherit the wealth, there must be clear relationship between both of them, such as: parent-child relationship, husband-wife relationship, and sibling relationships, either sibling, same father or same mother.

In addition, it should be noticed whether there is the inheritance obstacle or not. In Islamic Inheritance Law, there are three inherited obstacles: ${ }^{13}$ first, being slave. A slave does not receive an inheritance because all his wealth belongs to his master. If we give the inheritance from his relatives, it will automatically

\footnotetext{
${ }^{9}$ Afidah Wahyuni, 'Sistem Waris dalam Perspektif Islam dan Peraturan Perundang-Undangan dii Indonesia', Salam: Jurnal Sosial Dan Budaya Syar'i 5, no. 2 (2018): 152, https://doi.org/10.15408/sjsbs.v5i2.9412.

10Wati Rahmi Ria, 'Aspek Yuridis Tentang Hukum Waris Islam' (Universitas Lampung, 2008), 39.

${ }_{11}^{1}$ Moh. Muhibbin and Abdul Wahid, Hukum Kewarisan Islam sebagai Pembaruan Hukum Positif dii Indonesia (Jakarta: Sinar Grafika, 2009), 61.

12Muhibbin and Wahid, Hukum Kewarisan Islam sebagai Pembaruan Hukum Positif Di Indonesia, 62.

13Abu Malik Kamal, Tuntunan Praktis Hukum Waris: Lengkap dan Padat Menurut Al-Qur'an dan AsSunnah yang Shahih (Jakarta: Pustaka Ibu Umar, 2009), 15-17.
} 
become his master's. It means that there is inheritance to others without any reason.

Second, murder. The Hanafiyah scholars divides the two types of murder, direct murder (mubāsharah) and indirect murder (tasabbub). The direct murder is divided into three: intentional murder, intentional-like murder, and unintentional murder. The indirect murder, such as someone making a hole in his garden, then there are people who fall into that hole and die. The death of the victim because of what it does not directly undertaken by the person who make it. According to Hanafiyah scholars, direct murder is an obstacle to inherit, while indirect murder is not. ${ }^{14}$

Third, different religion. Different religion means the religion of the testator is different from the religion of the heir. It is based on the words of the Prophet, "A Muslim can not inherit the wealth of kafir and he was not able to inherit the wealth of the Muslim". (HR. Bukhari Muslim)

\section{Phenomenon of Adopted Children}

The definition of adopted child is a child whose rights are transferred from the parent-power families, legal guardian, or other people who are responsible for the care, education and raising the child into the adoptive parents' family based on the court decision. ${ }^{15}$ According to the Compilation of Islamic Law, adopted child is a child who is taken care of his daily lives, education costs and so on, and the responsibility turns from the biological parents to his adoptive parents based on the court's decision. ${ }^{16}$

The provisions of this article implicitly emphasize that the adoption of a child causes the transfer of responsibilities from the biological parents to his adoptive parents in terms of caring for daily lives, education costs and so on, while the nasab relationship, marriage guardian for adopted daughter, and the inherit rights from biological parents are not broken. ${ }^{17}$ In Islam the legal

\footnotetext{
${ }^{14}$ Fikri and Wahidin, "Konsepsi Hukum Waris Islam dan Hukum Waris Adat: Analisis Kontekstualisasi Dalam Masyarakat Bugis," Al-Ahkam: Jurnal Ilmu Syari’ah Dan Hukum 1, no. 2 (2016): 199.

${ }^{15}$ Article 1 Verse 9 Law of RI Number 35 in 2014 about the Changes of Law Number 23 in 2002 about Children Protection Jo. Article 1 Point 1 Government Regulation Number 54 in 2007 about Practice of Child Adoption.

${ }^{16}$ According to Article 171 Islamic Law Compilation (KHI).

17Musthofa, Pengangkatan Anak Wewenang Pengadilan Agama (Jakarta: Kencana Prenada Media Group, 2008), 21.
} 
adoption of a child is not attaching a nasab to the adopted child so that it does not affect maritalism or mahram and inheritance. It can be understood from alAhzāb verse 37, where the asbabun nuzul is when the Prophet was commanded by Allah to marry Zaynab who was the ex-wife of his adopted son named Zayd bin Harisah.

The adoption of a child is a positive action in our customary law with various motivations, in accordance with the social diversity and forms of kinship in Indonesia. The consequences of legal child adoption are an appearance of civil law such as livelihood, child care and inheritance between the adopted child and adoptive parents. ${ }^{18}$

Law Number 23 in 2002 about Child Protection states strictly that the purpose and motivation of adopting children can be done only for the best interests of the child and is based on local customs and the provisions of the applicable laws and regulations. The practice of adopting child, with commercial motivations for human trafficking or just for provocation of having a child then the adopted child is neglected, is very contrary to the inherent rights of the child.

In fact, children adoption in Indonesia has a number of goals and motivations. One of the aim is to continue the lineage if in a family does not have children. This motivation is very strong for married couples who have been convicted of not being able to get children / it is not possible to give birth to children due to some reasons, such as infertility. Though they really want the presence of a child in their family. ${ }^{19}$

Thus the adoption of a child is a positive action in our customary law with a variety of existing motivations, in accordance with the diversity of society and forms of kinship in Indonesia. Staatblad 1917 No. 219 determines that the legal consequences of adoption are as follows:

a. Article 11: Adopted child legally has the name of the descendants of the adopters.

b. Article 12 paragraph 1: adopted child is made as a child born to the person who adopts. Consequently, the adopted child becomes the heir of the person who adopts.

\footnotetext{
18Susiana Susiana, 'The Rights of Adopted Child Towards the Inheritance of Adopted Parents', Kanun Jurnal Ilmu Hukum 13, no. 55 (2011): 140-42.

${ }_{19}$ Mutasir Mutasir, 'Dampak Hukum Pengangkatan Anak pada Masyarakat Desa Terantang Kec.Tambang Kabupaten Kampar Ditinjau dari Hukum Islam', Jurnal An- Nida' 41, no. 2 (2017): 17778.
} 
Meanwhile, according to Islamic law, adopted children are not recognized as basic and cause of inheritance, because the main principle in inheritance is blood relations or arham. However, in fact, in many places where the people are moslems, it still exists and regulates adoptions in which the adopted child may inherit wealth of adoptive parents. Even, because of their love to adopted children, inheritance has $b$ een running since the heir is still alive. ${ }^{20}$

\section{Position of Adopted Child}

The rules of the adopted children which are as a guideline of Religious Affair Court in Kudus is not much different from the rules of the adopted children in the perspective of Customary Law which is adopting other people's children into their own family in such a way so that between one who adopt the child and the adopted child have kinship, as happened between parents and their own biological children. ${ }^{21}$ Adopted children have certain rights and obligations related to its position in the structure of that family, such as using the family name called marga or clan, having the right to enjoy the family's facilities, and having to keep caring and helping. ${ }^{22}$

Islam admits that adoption is a noble thing because it is the same as helping children who are in need of help, especially orphans. Nevertheless, it must be understood that there are certain limits that have to be obeyed and do not have to be broken. For example, because it does not affect their mahram, it is not allowed when the children which have grown are treated as own children. However, they are not parents' mahram.

According to Public Relation of Kudus Religious Affair Court, the adopted child is someone who is kept for daily lives, education cost, and the transfer of responsibilities from biological parents to adoptive parents by a court decision.

The adoption of a child follows the formal process of Adoption Customary Law. This can be analyzed from the Supreme Court Decision No. $210 / \mathrm{K} / \mathrm{Sip} / 1973$ that to see the validity of adopted children depends on the implementation of custom ceremonies, without objectively examining the

\footnotetext{
${ }^{20}$ Hilman Hardikusuma, Hukum Waris Adat (Bandung: Citra Aditya Bakti, 2015), 72.

${ }^{21}$ Syamsuri, "Interview about Application of Inheritance Law in Kudus," PR of Kudus Religious Affair Court, 2019.

${ }^{22}$ Abdurrohman Kasdi, 'Marriage Counseling as an Effort to Build a Sakinah Family; Model of Fostering and Mentoring for Sakinah Families in Demak Regency', Jurnal Konseling Religi 10, no. 1 (2019): 99-115, https://doi.org/http://dx.doi.org/10.21043/kr.v10i1.5500.
} 
existence of the child in the family life of his adopted parents The admission requirement for an adopted child can be seen from the Supreme Court Decision of the Republic of Indonesia Number $912 \mathrm{~K} / \mathrm{Sip} / 1975$ which states that without going through a custom ceremonial procession, the adoption of child is invalid even though he has raised since a child and married by his adopted parents.

As the development of Law and the grown justice in society goes by, this idea has changed by appearing of new idea to identify someone whether he is an adopted child or not, does not only depend on the adoption as a formality, but also the existing reality to whom he has been cared for, circumcised, schooled, and married. This gets along with the Supreme Court Decision Number 53 K/Pdt/1995 on March 18, 1996.23

The motivation for children adoption in customary law is different from the motivation for children adoption in Child Protection Law. Because it emphasizes that a legal act of adoption must be based on not only the best interests of the child. In customary law, it more emphasizes on the concerns of prospective adoptive parents would their extinction, then they (couples who do not have kids) raise a child from the family relatives who do it voluntarily. Consequently, those children have the position as own child of adopted parents and he is separated from the former family.

Based on this study, it is found that the position of adopted children in Kudus is not much different from biological children, where adopted children are defined as the act of taking children from other people into their own families, so there will be a kinship between the adopted person and the adopted child as if it is between parents to their biological child. Adopted children have certain rights and obligations related to their position in their adopted families, for example, they may also use family names that are usually called clans, have the right to enjoy family's facilities, keep caring and helping and so on.

In addition, based on the research, it is also found that in Islamic Law Compilation, the existence of an adopted child can not be recognized as a basic and cause of inheritance, because the basic principle in Islamic inheritance law is their blood relations/nasab/descent. ${ }^{24}$ Thus, the adoption by KHI does not influence toward the status of adopted children. If children are not their own,

\footnotetext{
${ }^{23}$ Rehngena Purba, 'Hukum Adat dalam Yurisprudensi', Varia Peradilan 20, no. 260 (2007): 38-46.

24Zamzami Zamzami, 'Kedudukan Anak Angkat dalam Perspektif Hukum Perdata, Hukum Adat, dan Hukum Islam', Jurnal Nurani 17, no. 1 (2017): 29-31.
} 
then it can not be inherited from the parents who have raised them. According to KHI, adoption of a child can only be allowed if it has fulfilled the provisions, including not breaking the child's relationship with biological parents. Moreover, the position of adopted children is not as the heir of his adopting parents, the adopted children do not use names of the adopting parents directly, the adopting parents are not able to be a marriage guardian of his adopted children. 25

PR of Kudus Religious Affair Court explained that among the consequences of the adoption law is about the status of the adopted child is as heir of his adopting parents. According to KHI, the adopted child can not be legalled to be the basic and cause of inheritance, because the basic principle in the Islamic Inheritance Law is having blood relations/nasab/descent. It means that the adoption according to KHI does not carry the impact of Law toward the status of adopted children. If they are not parents' own children, then they can not inherit from their adopting parents, but the heir relationship still from the biological parents, as well as the nasab relationship.

According to Public Relations of Kudus Religious Affair Court, adoption can only be allowed if it meets the following provisions: First, it does not remove blood relationship between biological parents and the adopted child. Second, his position does not become the heir from the adopting parents, but the heir relationship is still from the biological parents, as well as the nasab relationship (having the father's name or bin is from biological father not from the dopting father). Third, one who have the right to inherit the wealth of the adopted child is only his biological parents (not the adopting parents). According to him, the adopted child based on Customary Law generally is taking a child based on the custom which has the similarity and/or recognition of kinship with his adopting parents and makes the break of his relationship with the biological parents. ${ }^{26}$

In terms of the position of adopted children as heirs to the inherited wealth of adopted parents, basically all research informantion states that the adopted children are not included in the category of heirs. Therefore, basically, adopted children do not inherit the inheritance of their adopted father. However, in the description of inheritance in general, that adopted children are the same

\footnotetext{
25Fauzi Fauzi, "The Concept of Patah Titi: The Problem of Inheritance and Its Solution in Aceh Tengah', Studia Islamika 26, no. 1 (2019): 44-46, https://doi.org/10.15408/sdi.v26i1.6529.

${ }^{26}$ Syamsuri, 'Interview about Application of Inheritance Law in Kudus'.
} 
position as biological children, they still deserve inheritance. The informant of this research uses simple conflict theory in which Law is needed when conflicts occur in inheritance distribution. It means that when there is no conflict in which all family members agree to include adopted children as heirs, then there is no problem in that matter. Another exception to the position of adopted children as heirs is when adopting parents do not have biological children.

It is expected for people who are going to adopt a child to do the process formally to the State Court so that the existence of the child is getting stronger and adoption not only for reasons of not having the descent yet, but it is based on love and having child's welfare. Kudus people, who will adopt the child, understand the procedures and process of adopting child in accordance with the provisions of Islamic teachings. State Court and Religious Affair Court in Kudus should also socialize KHI more, especially with regard to adoption, so that in the future disagreement does not happen again related to the adopting parents and adopted children..$^{27}$

\section{Inheritance Rights of An Adopted Child}

In Islamic law, between adopted children and adopting parents there is no inherited relationship. Therefore, the position of adopted children is very weak in this matter, especially if he does not have a legal letter related to the adoption. On the other hand, the fact sometimes does inverse in which the adopted child controls all inheritance of the adopting parents. By the reason, he has helped adopting parents so much. These two phenomena then create the problem of inheritance law which became the authority of the Religious Affair Court.28

Islam teaches kinship system based on religious teachings and in accordance with the conditions of the family. It determines the child's rights and obligations as well as limitations based on Islam teachings. Islam also improves the tradition of adoption and takes back the nasab relationship to the essential causes, such as the blood relation between the exactly parents and children.

This relationship is the relationship of feeling and manners. It does not have the usual consequences and necessities such as inheriting each other and paying diyat which are all consequences of blood relations. This is done so that the

\footnotetext{
${ }^{27}$ Eka Susylawati, 'Penerapan Hukum Waris Islam Dalam Perkara Waris di Pengadilan Agama Pamekasan', Al-Ihkam 9, no. 2 (2014): 326-27.

28Syamsuri, 'Interview aboutApplication of Inheritance Law in Kudus'.
} 
adopted children are not free and ignored without any bond at all in the family after the relationship of the child adoption is abolished. This Nash "... and if you don't know their fathers...", can illustrate how chaotic the family institution is in jahiliyyah period and this is what Islam wants to correct and justify by building a family system on the foundation of biological parent relations and also by building a community system on the principles of a healthy, safe and correct family.

The legal consequences of the adoption according to customary law are variative, it means that it may be different the customary law from one area to another. For example, in customary law of Minang, although the child adoption is the allowed action, this event does not cause the consequences of inheritance between the adopted child and the adopting parents. Meanwhile in areas that adopt a bilateral kinship system (parental), such as in Sulawesi, Java and Kalimantan, the child adoption has inheritance consequences. According to Javanese custom, there is the term "ngangsu sumur loro" to describe the inheritance of adopted children. The word "ngangsu" means looking for, "sumur" means water or well, and "loro" means two. The principle insists that adopted children inherit from two sources, from adopting parents and biological parents. ${ }^{29}$

Based on interviews conducted by the Public Relation of Kudus Rligious Affair Court stated that customary law generally relies on social normative rules in thinking concretely which has become a tradition of certain society. One of them, in Kudus, people shares inheritance by customary law, which is substantially the main source of customary law itself and Islamic law. From each family, it is usually found that there is an adopted child who inherits from his adopting parents. ${ }^{30}$

In the right of inheritance law in Kudus that generally relies on normative social norms in thinking concretely, which has become a tradition of certain society. One of them is the Kudus Regency community which shares inheritance with customary law which is substantially the main source of customary law itself and Islamic law. From each family, it is usually found that there is the adopted child who inherits from his adopting parents. Usually the distribution

\footnotetext{
${ }^{29}$ A. Rachmad Budiono, Pembaruan Hukum Kewarisan Islam di Indonesia (Bandung: Citra Aditya Bakti, 1999), 189.

${ }^{30}$ Syamsuri, 'Interview about Application of Inheritance Law in Kudus'.
} 
of inheritance also depends on each of which is carried out by consultation and agreement of family members.

In applying Islamic Inheritance Law, especially in KHI mentioned the inheritance basic on article 174 verse (1) members of heirs consist of: first, according to blood relations. The male group consists of: father, son, brother, uncle and grandfather. Whereas the female group consists of: mother, daughter, sister and grandmother. Second, according to the marital relationship, it consists of: widow or widower. The adopted children are not included in the category, because adopted children are not a relative with their adopting parents, and are not biological children of adopting parents, so adopted children cannot inherit their adopting parents, and vice versa. ${ }^{31}$

Islamic Law Compilation emphasizes that between the adopting parents and adopted children, there is no relationship of inheritance, but as a form of recognition to the adoption institution, their relationship is confirmed by wasiat wajibah (will), to distinguish it from the position of heir, This adopted child arrangement is regulated in chapter $\mathrm{V} \mathrm{KHI}$ concerning wills. ${ }^{32}$

A will is one form of ownership of wealth known and recognized in Islamic law, in addition to other forms of ownership. ${ }^{33}$ The practice of wills has well known long time ago before Islam came, but in practice, it did not have clear rules. At that time, everyone was free to give his assets to anyone he wanted, without the supervision and regulations which govern them.

\section{Implementation of Inheritance Distribution of Adopted Child in Kudus}

Applying the distribution of the inheritance for the adopted child in Customaary Law in Kudus, is conducted through two forms: First, by giving will, either will or having portion regulations to the adopted child in inheritance. ${ }^{34}$ Second, some regulations of Customary Law state the portion of the adopted child is egual to biological child portion (if there is inheritance right).35 In

\footnotetext{
${ }^{31}$ Sofyan Mei Utama, 'Kedudukan Ahli Waris Pengganti dan Prinsip Keadilan dalam Hukum Waris Islam', Jurnal Wawasan Hukum 34, no. 1(2016): 69-70.

32Budiono, Pembaruan Hukum Kewarisan Islam di Indonesia.

33Diana Zuhroh, 'Konsep Ahli Waris dan Ahli Waris Pengganti: Studi Putusan Hakim Pengadilan Agama', Al-Ahkam 27, no. April (2017): 44.

${ }^{34}$ Agus Yusrun Nafi', "Interview about Giving Will, Wither Will or Having Portion Regulations to the Adopted Child in Inheritance," The Religious Instructor The Ministry of Religious Affairs of Kudus District, 2019.

35Syamsuri, 'Interview about Application of Inheritance Law in Kudus'.
} 
inheritance rights in Kudus, generally relies on normative social norms in thinking concretely, which has become a tradition of certain society. One of them, Kudus people divides the inheritance by Customary Law, which are substantially a main source of Customary Law itself and Islam Sharia. Of each family members, it is usually found that there are adop ted children who get inheritance from the adopting parents.

Meanwhile, people in Kudus who hold KHI tend to argue that adopted children get mandatory wills. This is based on Article $290 \mathrm{KHI}$ paragraphs 1 and 2 which can be understood that the will referred to $\mathrm{KHI}$ is a will which is required under the provisions of Law intended for adopted child or in turn, adopting parents who are not given a will before by adopting parents or his adopted child, with a maximum of $1 / 3$ of the inheritance. In accordance with the words of the Prophet Muhammad, to Sa'ad bin Abi Waqqas, the majority of scholars agreed that a total of inherited wealth must not be more than the heir, if he has the heir. Because Rasulullah stated that the total of the inherited wealth in the hadith is: "one third, and one third is too much...".

Will is one of the form of ownership of the wealth which is known and recognized in Islam Sharia, in addition to other forms of ownership. The practice of will has already be known long time ago before Islam came, but in fact, it did not have clear rules. At that time, everyone gave their own wealth freely to whoever they wamted without any regulating supervision and regulation.

The Islamic Law Compilation in Indonesia requires the testator at least at the age of 21 years, healthy, and no force from the other. Fiqh scholars also agreed to require the recipient of a will. The requirements of will recipient are: the heir is pointed specifically that he has the right to get inheritance. He must have clear identity so that the will can be given to him. He is not in the area of the enemy. He is not a person who kill the testator, if the testator is murdered. He is not kafir harbi (Kafir who fight Islam), however it is allowed to kafir dzimmi as long as he is fair.

It goes with the statement of the Public Relations of Kudus Religious Affair Court which stated that in determining the portion of inheritance for adopted children, the Compilation of Islamic Law also regulates the obligatory wills (wasiat wajibah) in which it is determined by legislation even though the related person does not inherit it. This is intended for heir's parents and adopted children who in the perspective of Islamic Law are not entitled to inheritance. The provisions of the obligtory wills are regulated in Article $209 \mathrm{KHI}$ which states that the adopting parents who do not receive a will are given the obligatory will of $1 / 3$ of the inheritance of the adopted child and for adopted 
children who do not receive the the will are given a obligatory will of $1 / 3$ of the adopting parents' wealth.

PR of Kudus Religious Affair Court said that Customary Law basically adopts and applies the existing law in a particular area, the source of the law is different. Kudus is a regency which the majority people are muslims (religious) so that Kudus also known as the "City of Santri". Therefore, the customary inheritance Law certainly goes along with the Islamic inheritance Law. ${ }^{36}$ As held by most people in Kudus, there is the Fiqh rule, "al-'ädah muhakkamah". Therefore, the distribution of adopted children's inheritance according to customary law and Islamic law (KHI) in Kudus is the same in which the adopted child does not get an inheritance from his adopting father, he can only receive the inheritance from his adopted parents through the obligatory will which is not more than $1 / 3$ of the total inheritance of his adopted parents." 37

According to PR of Kudus Religious Court, the obstacles which appear in the distribution of inheritance are caused by families who do not share their understanding or are different and some even have other desires so that there is one more dominant family member which regulates (determinants). Moreover, the obstacle is each of them wants a different division, there must be according to Islamic law with the portion as mentioned above and there are also those who want the same without making a problem either men or women.

For this reason, the effort which must be dealt with is to provide legal counseling to the society, increase public awareness about asset which is something that has strategic value, additional value so that in the future, it will costly. To avoid leaving the inheritance intact, it is better that the death of the heir at that time can also be immediately divided for inheritance. Distribution of inheritance which is carried out for a long period from the death of the testator, it will add to the complexity of the distribution of inheritance, such as the main heir who died leaving children and so on.

\section{Conclusion}

The position of adopted children's inheritance in customary law are the same as biological children (in one area and not the same to another because each region has a customary law which has a different style). Adopted child according to custom is generally the traditional adoption which has similarity

\footnotetext{
36Komari Komari, 'Eksistensi Hukum Waris di Indonesia: Antara Adat dan Syariat', Jurnal AsySyari'ah 17, no. 2 (2015): 157-72.

${ }^{37}$ Nafi', "Interview about Giving Will, Wither Will or Having Portion Regulations to the Adopted Child in Inheritance."
} 
and or acknowledgment of kinship with his adopting parents and makes the child's relationship with the biological parents / families come to an end. Whereas the position of adopted children in the Compilation of Islamic Law is clear as mentioned above in which the position of adopting parents is only in the responsibility of caring, education costs and more which transfer to the adopting parents so that it is not the same as biological children in the case of inheritance or nasab.

Inheritance rights of adopted children according to customary law are varied, it means that one area has different customary law to another. According to inheritance issues, there are also variations in legal provisions, in terms of inheritance rights, there are various provisions. Because of the adoption, it causes a relationship of inheritance between adopting parents and adopted children and breaks the inheritance of adopted children with their biological parents. There is also a reason for adoption of children is only as an appointment without inheritance rights. In fact, because of the adoption of the child, the inheritance relationship with the adopted child and biological parents still exist and the relationship of the inheritance of the adopted child with biological parents arises due to the adoption of the child. Meanwhile, the inheritance rights of adopted children according to Islamic Law Compilation, there is no inheritance relationship between adopted children and their adopted parents. The adoption of children in Islamic law is limited to welfare, taking care of adopted children from neglect, so that the relationship between adopted children and their biological parents still remains.

The application of the distribution of inheritance for adopted children in customary Law in Kudus states that the portion of adopted children is equal to the portion of biological children (if there is inheritance rights) or by the will of the adopting parents. Meanwhile, the application of the Islamic Law Compilation in the distribution of inheritance in Kudus also regulates the obligatory will, a will without a will and it is determined by Law even if the related person does not inherit it. This is intended for parents and adopted children of heirs who in the perspective of Islamic law are not entitled to inheritance. The provisions of the obligatory wills are regulated in article 209 of the Islamic Law Compilation which regulates that for adoptive parents who do not receive a will are given a mandatory will of one third of the inheritance of adopted children and for adopted children who do not receive a will are given a mandatory will from the inheritance of his adopting parents.

Law in Indonesia is pluralism. Therefore, the Government in setting Laws, especially regarding inheritance for adopted children, should be able to see from the similarities and differences that exist from the existing legal systems in 
Indonesia. Then, Laws or regulations which have been made can be enforced for all Indonesians.[a]

\section{BIBLIOGRAPHY}

'According to Article 171 Islamic Law Compilation (KHI)', n.d.

Al-Fahmi, Mifa. 'Warisan Anak Angkat Menurut Hukum Adat dan Kompilasi Hukum Islam'. USU Law Journal 5, no. 1 (2017).

'Article 1 Verse 9 Law of RI Number 35 in 2014 about the Changes of Law Number 23 in 2002 about Children Protection Jo. Article 1 Point 1 Government Regulation Number 54 in 2007 about Practice of Child Adoption', n.d.

Budiono, A. Rachmad. Pembaruan Hukum Kewarisan Islam di Indonesia. Bandung: Citra Aditya Bakti, 1999.

Depag, Tim Penyusun. Fiqih. Edited by Departemen Agama. Jakarta, 2002.

Fauzi, Fauzi. 'The Concept of Patah Titi: The Problem of Inheritance and Its Solution in Aceh Tengah'. Studia Islamika 26, no. 1 (2019): 33-74. https://doi.org/10.15408/sdi.v26i1.6529.

Fikri, and Wahidin. 'Konsepsi Hukum Waris Islam dan Hukum Waris Adat: Analisis Kontekstualisasi dalam Masyarakat Bugis'. Al-Ahkam:Jurnal Ilmu Syari'ah dan Hukum 1, no. 2 (2016): 193-204.

Franz, and Keebet Von Benda-Beckmann. 'Islamic Law in a Plural Context: The Struggle over Inheritance Law in Colonial West Sumatra'. Journal of the Economic and Social History 55 (2012): 771-93. https://doi.org/ 10.1163/15685209-12341269.

Hapsin, Abu. 'How to Make Islamic Law as The State Legal Policy of Indonesia: Constitutional and Sociological Arguments'. Al-Ahkam 27, no. 2 (2017): 139-56.

Hardikusuma, Hilman. Hukum Waris Adat. Bandung: Citra Aditya Bakti, 2015.

Kamal, Abu Malik. Tuntunan Praktis Hukum Waris: Lengkap dan Padat Menurut Al-Qur'an dan As-Sunnah yang Shahih. Jakarta: Pustaka Ibu Umar, 2009.

Kasdi, Abdurrohman. 'Marriage Counseling as an Effort to Build a Sakinah Family; Model of Fostering and Mentoring for Sakinah Families in Demak Regency'. Jurnal Konseling Religi 10, no. 1 (2019): 99-115. https://doi.org/http://dx.doi.org/10.21043/kr.v10i1.5500. 
Komari, Komari. 'Eksistensi Hukum Waris di Indonesia: Antara Adat dan Syariat'. Jurnal Asy-Syari'ah 17, no. 2 (2015): 157-72.

Miles, Matthew B., and A. Michael Huberman. Analisis Data Kualitatif.Jakarta:UIPress, 2000.

Muhibbin, Moh., and Abdul Wahid. Hukum Kewarisan Islam sebagai Pembaruan Hukum Positif di Indonesia. Jakarta: Sinar Grafika, 2009.

Musthofa. Pengangkatan Anak Wewenang Pengadilan Agama. Jakarta: Kencana Prenada Media Group, 2008.

Mutasir, Mutasir. 'Dampak Hukum Pengangkatan Anak pada Masyarakat Desa Terantang Kec. Tambang Kabupaten Kampar Ditinjau dari Hukum Islam'. Jurnal An-Nida' 41, no. 2 (2017): 173-92.

Nafi', Agus Yusrun. 'Interview about Gving Will, Wither Will or Having Portion Regulations to the Adopted Child in Inheritance', 2019.

Nazir, Moh. Metode Penelitian. Bogor: Ghalia Indonesia, 2017.

Purba, Rehngena. 'Hukum Adat dalam Yurisprudensi'. Varia Peradilan 20, no. 260 (2007).

Ria, Wati Rahmi. 'Aspek Yuridis tentang Hukum Waris Islam'. Universitas Lampung, 2008.

Sugiono. Metode Penelitian Pendidikan: Pendekatan Kuantitatif, Kualitatif dan $R$ \& D Educational Research Methods: Quantitative, Qualitative and $R \& D$ Approaches. Bandung: Alfabeta, 2008.

Susiana, Susiana. "The Rights of Adopted Child Towards the Inheritance of Adopted Parents'. Kanun Jurnal Ilmu Hukum 13, no. 55 (2011): 139-48.

Susylawati, Eka. 'Penerapan Hukum Waris Islam dalam Perkara Waris di Pengadilan Agama Pamekasan'. Al-Ihkam 9, no. 2 (2014): 316-37.

Syamsuri. 'Interview about Application of Inheritance Law in Kudus', 2019.

Utama, Sofyan Mei. 'Kedudukan Ahli Waris Pengganti dan Prinsip Keadilan dalam Hukum Waris Islam'. Jurnal Wawasan Hukum 34, no. 1 (2016): 6886.

Wahyuni, Afidah. 'Sistem Waris dalam Perspektif Islam dan Peraturan Perundang-Undangan di Indonesia'. Salam: Jurnal Sosial dan Budaya Syar'i 5, no. 2 (2018): 147-60. https://doi.org/10.15408/sjsbs. v5i2.9412.

Yasin. Titik Temu Hukum Waris di Indonesia. Yogyakarta: Idea Press, 2011. 
Abdurrohman Kasdi, Khoiril Anwar

Zamzami, Zamzami. 'Kedudukan Anak Angkat dalam Perspektif Hukum Perdata, Hukum Adat, dan Hukum Islam'. Jurnal Nurani 17, no. 1 (2017): 27-40.

Zuhroh, Diana. 'Konsep Ahli Waris dan Ahli Waris Pengganti: Studi Putusan Hakim Pengadilan Agama'. Al-Ahkam 27, no. April (2017): 43-58. 